\title{
THE USE OF WORD-BUILDING MORPHEMES IN FORMATION OF GERMAN YOUTH VOCABULARY
}

\begin{abstract}
Summary. The article examines word-building processes by means of suffixes and prefixes in German youth vocabulary. This language subsystem reflects worldview, everyday life, way of thinking, value system, and contacts of a particular social and age group. Young people use verbal means to express their uniqueness and demonstrate separation from other members of the society. Thus, extralingual factors have significant impact on the development of youth vocabulary. In the formation of the analyzed lexical units, the most productive are suffixes, which are used to name people. These lexical units have clearly seen positive or negative connotation. Given that youth vocabulary is a subsystem of the modern German language, there is a parallel with its word-building processes. The suffixes -er and -el are the most productive in the formation of nouns denoting male people. At the same time, the studied language phenomenon includes words formed by means of suffixes, which are not typical for morphologic structure of lexical units of standard German. The popularity of these word-building morphemes in the vocabulary of the studied language subsystem can be determined by the desire for self-expression among representatives of other social or age groups, the protest against word-building rules of standard German, the try to attract attention of communicative partners, the search for expression of subjective attitude to the environment. In the analyzed vocabulary, prefixation is most productive for formation of verbs. This process is characterized by the use of morphemes, which are typical for word-building of the modern German language in general. The author has singled out the most productive prefixes of verbs in the analyzed material. The use of prefixes in the formation of nouns and adjectives is often aimed to satisfy the young people's need for exaggeration. Young people also show their creativity by changing word-building meanings of prefixes. For example, the prefix inter- is used in German youth vocabulary to intensify the meaning of the word. As a rule, this process is accompanied by semantic changes of the root morpheme.
\end{abstract}

Key words: suffixation, prefixation, semantic changes, productivity, exaggeration, connotation.

Formulation of the problem. Vocabulary of the modern German language is a complex system that consists of various interconnected subsystems. Its structure includes words and phrases created and used by representatives of different professional, ethnic, social, and age groups.

These language subsystems represent traditional sources to enrich the vocabulary of German-speaking community. All of them more or less intensively influence the development of colloquial and literary styles of German, determining main features and trends of this process. They also play an important role in semantic changes of commonly used lexical and phraseological units.
Youth vocabulary is one of the components that form the basic for the modern German language. The given language subsystem is characterized by its formal exraordinariness and a high value of pragmatic use. At the same time, it is closely interconnected with other substandard vocabulary systems.

Youth vocabulary reflects worldview, everyday life, way of thinking, value system, and contacts of a particular social and age group. Conceptual system of the representatives of the given part of German-speaking community differs significantly from the conceptual system of adults. Through language, young people look for ways to express their uniqueness. At the same time, they use verbal means for demonstrating separation from the society and its rules which seem them confusing and hostile.

The above-mentioned factors often play a determining role in the formation of lexical units of German youth vocabulary. Therefore, the article is aimed to find out the peculiarities of wordbuilding processes of German youth vocabulary on the example of suffixation and prefixation models.

Analysis of resent research and publications shows that formation of German youth vocabulary has been studied by a number of scientists for a long period of time. In particular, J.K. Androtsopoulos examines different types of word-building, productive morphemes, as well as functions of word-building in German youth vocabulary [1, p. 79-219]. H. Henne describes the given linguistic phenomenon as a means of communication of a corresponding social and age group [2]. The work of P. Schlobinski P. and H.-Ch. Heins is devoted to empirical study of using of analyzed vocabulary in the activities of various youth styles and subcultures [3]. At the same time, K.V. Kulakova identifies youth vocabulary as dynamic and changeable [4, p. 25], pointing to the influence of modern technologies and networks on its development [4, p. 26-28]. N.V. Shamova and L.N. Ponomarenko study word-formation types of modern German vocabulary and describe their systemic paradigmatic relations [5, p. 177-185].

Scientific novelty of the article is that the connection between using of certain word-building morphemes and extralingual determinants of their productivity has been examined. The study provides for combining the theoretical basis of fundamental works on word-building of German language $[6 ; 7]$ with the latest approaches in research of youth vocabulary.

The purpose of the article is quantitative and qualitative description of derivates formed by means of suffixation and prefixation models in German youth vocabulary. Extralingual factors of functioning and development of the analyzed linguistic phenomenon are taken into consideration.

Thus, the subject of research is the formation of German youth vocabulary by means of suffixation and prefixation. The object 
of research are words of three main syntactic categories (nouns, verbs, adjectives) chosen from modern dictionaries of German youth vocabulary $[8 ; 9 ; 10]$.

Results and discussion. The results of the study have shown that suffixation is a productive way of formation of new lexical units of German youth vocabulary. Being considered as an indicator of lexical generalization [7, p. 74], the given type of word-building morphemes is used by young speakers to emphasize subjective judgement and assessment.

In the formation of the analyzed vocabulary, the most productive are suffixes, which are used to name people (both young and adult ones). In our opinion, this can be explained by a large number of words that belong to this semantic group. For its part, the given factor is determined by the need to show the attitude to the communicative partner and other members of the society as well. Therefore, the above-mentioned lexical units have clearly seen positive or negative connotation. Thus, the verbal sef-identification of young people is realized by means of pointing to subjectively highlighted features of the referred person.

Given that youth vocabulary is a subsystem of the modern German language, there is a parallel with its word-building processes. Like in standard German, the suffixes -er and -el are the most productive in the formation of nouns denoting male people. They are added to the roots of nouns and verbs (Bringer - alles, was gut oder im Trend ist; Muckel - schweigsame, verschlossene Person). In the analyzed material, the suffix -er to is also recorded in its variant -iker (Problemiker - Person, die ständig mit sich bringt).

The use of the productive suffixes -loge and -us is characterized by semantic changes of the morpheme, in particular, by metaphorization (Promillologe - Gewohnheitstrinker, Säufer, Verkehrspolizist; Müllologe - Schwätzer).

At the same time, German youth vocabulary includes words formed by means of suffixes, which are not typical for morphologic structure of lexical units of standard German. These are the formants $-i$ and $-o(-i k o)$. They can be regarded as an alternative to the suffix -er. The connotation of the given words shows ironic attitude and helps to emphasize positive or negative features of the referred person (Draußi-Person, die gerne an der frischen Luft ist; DrinniStubenhocker; Anarcho-Anarchist).

The above-mentioned suffixes can be added to:

- root morphemes of lexical units of colloquial and literary German without changing their basic sematics (Schrulli-schrullige Person, schwieriger Mensch; Karriero - jugendlicher KarriereVorzeigetyp);

- metaphorized root morphemes of lexical units of colloquial and literary German (Raffi-Person, die schnell begreift, was Sache ist; Schmacko - attraktiver Junge);

- root morphemes which are part of subcultural vocabulary (Grufti-einer, der in der Gruft liegt, (altmodische) Person jenseitsdes 30. Lebensjahres, Okkultist, Satansanbeter; Gollo-Idiot).

In our opinion, the popularity of these suffixes in the vocabulary of the studied language subsystem can be determined by the following extralingual factors:

- the desire for self-expression among representatives of other social or age groups;

- the protest against word-building rules of standard German;

- the try to attract attention of communicative partners;

- the search for expression of subjective attitude to the environment.
In youth vocabulary, a lot of feminine nouns are created by means of suffixation. In this case, the following word-building morphemes are the most productive:

-e (Schlunze - schlampig gekleidete Frau; Depresse niedergeschlagene weibliche Person);

-ei (Tummerei - Alkohol- oder Drogenrausch; Bräuterei Anmache, Mädchenjagd);

-ette (Hässlette - unattraktive Person; Mantalette - naives Mädchen).

The formation of neuter nouns is characterized by the use of the suffix -chen. This word-building morpheme is typical for suffixation processes in standard German. Therefore, the features of youth vocabulary as a language subsystem are shown. In the analyzed material, the given formant points to ironic attitude to the referred subject (Klärchen - Schnaps; Tittchen korpulenter Junge).

Suffixation of verbs is characterized by the use of the formant -eln. These words mainly have the meaning of action or state. The most productive word-building model is «noun + -eln» (bürsteln Sex haben; mupfeln - essen). The word-building model «adjective + -eln» is less productive (dümmeln - dumm daherreden, sich unqualifiziert äußern).

Two other productive suffixes -ieren and -ern, which are used to form verbs in German youth vocabulary, reflect a connection of affixation in the given language subsystem to the word-building of colloquial and literary types of German. These suffixes are usually added to metaphorized roots (diagnostikalisieren - unbeherrscht Alkohol trinken; brettern - sich schnell fortbewegen).

The most productive and frequent suffix in the formation of adjectives is -mäßig. These lexical units mostly express exaggerated assessment of people, things, actions etc. The given suffix can be added to the roots with various semantics and connotation (granatenmäßig - sehr gut, hervorragend; weltmäßig - toll, super).

The suffix -ig is used to point to similiarity, emphasizing a certain component in the semantic structure of the word. The word-building meaning often has negative connotation (assig widerlich, abscheulich; prollig-angeberisch).

The suffixes -lich, -haft, and -ös are used to form adjectives with the meaning of positive or negative description on the basis of metaphorization. On the one hand, they demonstrate language creativity of young people, on the other hand, they have a significant pragmatic effect (schläpplich - schwächlich, langweilig, fade, schlecht; didihaft-dumm; tubbitös - niedlich).

The function of prefixation is realized through changing the lexical meaning of the word without changing its syntactic category [7, p. 73]. That creates the preconditions for the use of the given model to form new lexical units of German youth vocabulary.

Young speaker's tendency to exaggerate in evaluating people and things is clearly seen in the use of the prefix Superfor the formation of nouns. This affix gives them the meaning of the highest degree of quality (Superbirne - Person mit hoher Denkintelligenz, Person mit wenig Denkintelligenz; Super-Bienegut aussehendes Mädchen).

Overestmation is considered to be a usual practice of young people's communication. That is why, the prefix Mini-, which gives nouns the meaning of small size, is less productive in youth vocabulary (Minipanzer - hässliches Mädchen, fettes Mädchen). 
In the studied vocabulary, prefixation is most productive for formation of verbs. This process is characterized by the use of wordbuilding morphemes, which are typical for the modern German language in general.

Having analyzed lexicographic sources, we have singled out the most productive prefixes of verbs:

- be- (behumsen - jemanden auf den Arm nehmen, betrügen; bekeimen-jemanden zulabern, vollquatschen; ansprechen);

- ver- (verdackeln - etwas verpassen, etwas vergessen; verbimsen, verhinkeln - verprügeln);

- zer-(zereiern-lauthals lachen; sich ärgern);

- ent-(entschleunigen - etwas langsamer angehen);

- er- (ergeiern-sich etwas ergattern, sich etwas (mehr oder weniger legal) beschaffen, betteln).

In these examples, the «youth» specificity of the formed lexical units is expressed by the root, which is often metaphorized (bekoffern-jemanden anpumpen; verdröseln - sich hängen lassen, faulenzen).

The use of prefixes in the formation of adjectives is often aimed to satisfy the young people's need for exaggeration. In this vocabulary, the dominant role is played by two intensifying formants hyper- and super-, which are popular with the representatives of German-speaking community in general (hypermatt - sehr matt; superschick-sehr schick).

However, we consider it necessary to add specific «youth» prefixes, which are also used to change the semantics of adjectives in terms of exaggeration. These formants are not specified as traditional prefixes of adjectives. They are borrowed from other languages and became popular because of their frequent use in mass-media and social networks. As a rule, semantic changes of the root morpheme are not typical for these words. The given prefixes just emphasize a particular feature or assessment, making the message more subjective:

- mega- (megahart - sehr hart; megastark - sehr stark);

- giga- (gigageil - sehr geil; gigadumm - sehr dumm);

- meta- (metahart - sehr hart; metatoll - sehr toll);

- turbo- (turbogeil - sehr geil; turbostark - sehr stark);

- ultra- (ultrakrass - sehr krass; ultrastark - sehr stark).

Young people also show their creativity by changing wordbuilding meanings of prefixes. For example, the prefix inter-is used in German youth vocabulary to intensify the meaning of the word. As a rule, this process is accompanied by semantic changes of the root. Thus, the creativity of young people is reflected in combining semantic transformation of the root and word-building morpheme (intergalaktisch - sehr gut, toll; intergeil - hervorragend).

Conclusions. Thus, in German youth vocabulary, affixes are used in some of their word-building meanings. There is a focus on one or more popular meanings. This choice is determined by the social and age peculiarities, worldview, values, activities, which form the core of young people's life.

For example, the tendency to exaggeration is reflected in the productivity of the prefixes super-, hyper- and meta-. The need for specification and subjective assessment is realized through the use of the suffix -er. The suffix -chen is preffed to emphasize ironic attitude in the process of denotation. Lack of clear ideas about the characteristics of the environment is expressed in the possibility of comparison by means of the suffix -mäßig.

During the study, we have singled out a number of morphemes that are not typical for word-building processes of standard
German. Their productivity in the analyzed material can be regarded as a result of the complex action of social and age factors that determine key features of youth vocabulary, in particular, the need for self-identification, creativity, protest, exraordinariness, exaggeration, and subjective assessment. Some of these suffixes and prefixes are borrowed from other languages and added to roots of German lexical units.

The results of the study can be used for description of wordbuilding models of other subsystems of the modern German language.

\section{References:}

1. Androtsopoulos J.K. Deutsche Jugendsprache. Untersuchungen zu ihren Strukturen und Funktionen. Frankfurt am Main : Peter Lang, 1998. 684 S.

2. Henne H. Jugend und ihre Sprache : Darstellung, Materialien, Kritik. Berlin; New York : de Gruyter, 1986. 385 S.

3. Schlobinski P., Heins H.-Ch. Jugendliche und «ihre» Sprache: Sprachregister, Jugendkulturen und Wertesysteme; empirische Studien. Opladen : Westdeutscher Verlag, 1998. 236 S.

4. Кулакова К.В. Молодежный сленг как отражение современной действительности. Вестник Балийского федерального университета им. И. Канта. Филология, педагогика, психология. Калининград, 2019. № 4. С. 23-30.

5. Шамова Н.В., Пономаренко Л.Н. Немецкий молодежный язык: словообразовательные типы суффиксальных существительных и их семантические связи. Научный диалог. 2020. № 5. С. 171-191.

6. Словарь словообразовательных элементов немецкого языка / А.Н. Зуев, И.Д. Молчанова, Р.З. Мурясов и др.; под рук. М.Д. Степановой. 2-е изд., стереотип. Москва : Русский язык, 2000. 536 с.

7. Степанова М.Д. Словообразование современного немецкого языка / под ред. Т.В. Строевой. 2-е изд., испр. Москва : КомКнига, 2007. $376 \mathrm{c}$.

8. Duden - Das neue Wörterbuch der Szenesprachen. Duden, 2009. $208 \mathrm{~s}$.

9. PONS 15 Jahre Wörterbuch der Jugendsprache - Sammelband : Das Original - unzensiert [1. Aufl.]. Stuttgart : PONS, 2016. $288 \mathrm{~s}$.

10. PONS Wörterbuch der Jugendsprache 2017. Stuttgart : PONS, 2016. $144 \mathrm{~S}$.

Поздняков О. В. Використання словотворчих морфем В утворенні німецького молодіжного вокабуляру

Анотація. У статті досліджуються процеси словотворення за допомогою суфіксів та префіксів у німецькому молодіжному вокабулярі. Зазначена мовна підсистема відображає світогляд, повсякденне життя, спосіб мислення, систему цінностей та контакти відповідної соціальної та вікової групи. Молоді люди використовують мовні засоби для демонстрації своєї неповторності та відособленості від інших членів суспільства. Отже, позамовні фактори мають значний вплив на розвиток словникового запасу молоді. Під час формування аналізованих лексичних одиниць найбільш продуктивними $є$ суфікси, що використовуються для найменування людей. Ці лексичні одиниці мають чітко помітну позитивну чи негативну конотацію. Враховуючи, що молодіжний вокабуляр $є$ підсистемою сучасної німецької мови, існує паралель із ії процесами словотворення. Суфікси -er та -el $є$ найпродуктивнішими під час утворення іменників, що позначають людей чоловічої статі. Водночас досліджуваний мовний феномен включає слова, утворені за допомогою суфіксів, не притаманних для морфологічної будови лексичних одиниць літературної 
німецької мови. Популярність цих словотворчих морфем у вокабулярі досліджуваної мовної підсистеми може бути визначена прагненням до самовираження серед представників інших соціальних чи вікових груп, протестом проти правил словотвору літературної німецької мови, спробою привернути увагу комунікативних партнерів, пошуком вираження суб'єктивного ставлення до навколишнього світу. В аналізованій лексиці префіксація $є$ найпродуктивнішою для утворення дієслів. Цей процес характеризується використанням морфем, типових для словотвору сучасної німецької мови загалом. Автор виокремлює най- продуктивніші префікси дієслів в аналізованому матеріалі. Використання префіксів під час утворення іменників та прикметників часто спрямоване на задоволення потреби молодих людей у перебільшенні. Молодь також демонструє свою креативність, змінюючи словотвірні значення префіксів. Наприклад, префікс inter- використовується в німецькій лексиці для підсилення значення слова. Зазвичай цей процес супроводжується семантичними змінами кореневої морфеми.

Ключові слова: суфіксація, префіксація, семантичні зміни, продуктивність, перебільшення, конотація. 